\title{
First record of terrestrial Enchytraeidae (Annelida: Clitellata) in Versailles palace's park, France
}

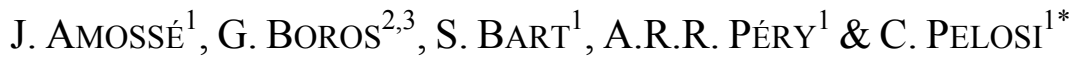 \\ ${ }^{1}$ Joël Amossé, Sylvain Bart, Alexandre R.R. Péry, Céline Pelosi, UMR ECOSYS, INRA, AgroParisTech, \\ Université Paris-Saclay, 78026, Versailles, France \\ ${ }^{2}$ Gergely Boros, MTA Centre for Ecological Research, Institute of Ecology and Botany, 2163Vácrátót, Hungary \\ ${ }^{3}$ Szent István University, Department of Zoology and Animal Ecology, 2100 Gödöllö, Hungary \\ *Corresponding author: UMR1402 INRA AgroParisTech ECOSYS, Bâtiment 6, RD 10, 78026 \\ Versailles cedex, France. Tel: (+33)1.30.83.36.07; Fax: (+33)1.30.83.32.59. \\ E-mail address: celine.pelosi@versailles.inra.fr
}

\begin{abstract}
France can be qualified as terra incognita regarding terrestrial enchytraeids because very little data has been recorded so far in this country. In spring and autumn 2016, enchytraeid communities were investigated in a loamy soil in a meadow located in the park of Versailles palace, France. In total, twenty four enchytraeid species were identified, belonging to six different genera i.e. eleven Fridericia species, four Enchytraeus species, four Achaeta species, two Buchholzia species, two Marionina species and one Enchytronia species. According to the published data, this was one of the highest diversity found in a meadow in Europe.
\end{abstract}

Keywords. Enchytraeids, Potworms, Soil fauna, Annelids, Oligochaeta, Meadow.

\section{INTRODUCTION}

$\mathrm{D}$ espite their key role in soils (Didden 1993), enchytraeids (Annelida: Clitellata) are so far poorly studied in many countries worldwide. To our knowledge, and except a few species recorded in Schmelz \& Collado (2010), no data have been published on enchytraeid communities in France, i.e., based on a literature search in the ISI Web of Knowledge, using the "All Databases" option, with the formula: '(enchytr* or potworm*) and (France or French) in Topics'.

Although some studies assessed enchytraeid community structures in grasslands, meadows and pastures, studying the influence of grazing (Schlaghamerský et al. 2007), liming (Davidson et al. 2004), fertilization (Sokołowska \& Seniczak 2005) or pesticides (Clements et al. 1987, Forsters et al. 1992, Martin 1975), most of them only reported a total abundance of enchytraeids (e.g. Clements et al. 1987, Francini et al. 2014, Van Vliet et al. 2006), without any details on species diversity. Yet, several authors recommended identifying the individuals at least at the genus level and if possible at the species level (Pelosi \& Römbke 2016). Indeed, indicators at the genus or species level appeared to be more sensitive to land use than total abundance. Moreover, taxonomic diversity provides key information on the requirements and sensitivity of the different species to environmental conditions, land use and management.

The objective of this study was to record the diversity of enchytraeids in a meadow in France and to compare it with other data in Europe.

\section{MATERIAL AND METHODS Study site}

Samples were collected in a meadow (about 1 ha, Figure 1.) located in the park of Versailles palace, France $\left(48^{\circ} 48^{\prime} 31^{\prime \prime} \mathrm{N}, 2^{\circ} 05^{\prime} 26^{\prime \prime} \mathrm{E}\right)$, which has not been cultivated since 1994. Before that time, it was conventionally cultivated with e.g. 


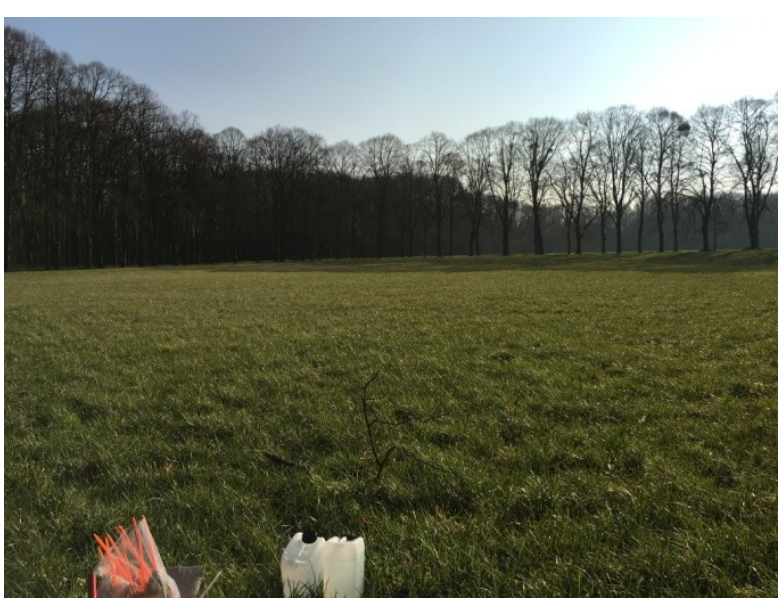

Figure 1. Meadow located in the park of Versailles palace.

barley, oats, beans, corn and wheat. The climate is oceanic temperate, with a mean annual temperature of $11{ }^{\circ} \mathrm{C}$ and a mean annual rainfall of $660 \mathrm{~mm}$. The soil is a deep Luvisol (FAO soil classification) developed on loess. The homogeneity of the physicochemical characteristics in the experimental site was verified by random sampling a soil core $(0-20 \mathrm{~cm}$ depth) at seven different locations in the site (Table 1.).

Table 1. Physicochemical characteristics of the soil at the experimental site ( $\mathrm{n}=7, \pm$ Standard Deviation)

\begin{tabular}{ll}
\hline Parameters & Meadow soil \\
\hline Texture (USDA, 1975) & Loamy soil \\
Clay (\%) & $22.9 \pm 0.7$ \\
Silt (\%) & $48.0 \pm 1.3$ \\
Sand (\%) & $29.1 \pm 1.2$ \\
$\mathrm{pH}_{\mathrm{H} 2 \mathrm{O}}$ & $7.5 \pm 0.2$ \\
$\mathrm{C}_{\text {org }}\left(\mathrm{g} \mathrm{kg}^{-1}\right)$ & $18.9 \pm 1.0$ \\
$\mathrm{~N}_{\text {tot }}\left(\mathrm{g} \mathrm{kg}^{-1}\right)$ & $1.5 \pm 0.1$ \\
$\mathrm{C}_{\text {org }} / \mathrm{N}_{\text {tot }}$ & $12.7 \pm 0.3$ \\
$\mathrm{P}_{2} \mathrm{O}_{5}\left(\mathrm{~g} \mathrm{~kg}^{-1}\right)$ & $0.08 \pm 0.01$ \\
$\mathrm{CaCO}_{3}\left(\mathrm{~g} \mathrm{~kg}^{-1}\right)$ & $23.3 \pm 8.1$ \\
$\mathrm{Cu}_{\text {tot }}\left({\left.\mathrm{mg} \cdot \mathrm{kg}^{-1}\right)}^{25.2 \pm 1.6}\right.$ \\
\hline
\end{tabular}

\section{Sampling and identification}

Ninety-six soil cores were sampled both in April and November 2016, following a regular grid of $60 \times 40 \mathrm{~m}$ and using a split soil corer (diameter of $5 \mathrm{~cm}$ ) at $0-5 \mathrm{~cm}$ and $5-10 \mathrm{~cm}$ depths. Each sample was transferred separately into a plastic bag and stored at $4{ }^{\circ} \mathrm{C}$. Enchytraeids were extracted using wet funnel extractors under a light from incandescent light bulbs. Soil samples were heated up for 3 hours (O'Connor 1959, Kobetičová \& Schlaghamerský 2003). All the individuals were kept in Petri dishes in tap water and counted. Adult and sub-adult individuals were identified at the species level under a light microscope (Olympus BX53) up to $400 \times$ magnification according to the key of Schmelz and Collado (2010).

\section{RESULTS}

In total, twenty four species of enchytraeids were identified, belonging to 6 genera. Species are listed below, with available information on their presence in Europe, habitat and life strategy (based on Graefe \& Schmelz 1999 and Schmelz \& Collado 2010):

Achaeta bohemica (Vejdovský, 1879): widespread, fresh soils, absent in wet habitats, slightly acid to slightly alkaline conditions, never in strongly acid soils, $K$-strategist, soil dweller.

Achaeta iberica Graefe, 1989: found in Spain, Italy (Schmelz and Collado 2000), and Switzerland (Amossé et al. 2016), only known from the original description.

Achaeta pannonica Graefe, 1989: widespread, fresh soils, absent in wet habitats, slightly acid to slightly alkaline conditions, never in strongly acid soils, $K$-strategist, soil dweller.

Achaeta unibulba Graefe, Christensen \& Dózsa-Farkas, 2005: widespread.

Buchholzia appendiculata (Buchholz, 1862): common and widespread in neutral to slightly acidic soils, $r / F$ (fragmenting)-strategist, litter dweller. 
Buchholzia fallax Michaelsen, 1887: widespread.

Enchytraeus buchholzi Vejdovský, 1879: widespread, very common, species complex, not in strongly acidic soils, $r$-strategist, OF (F-horizon dweller) and soil dweller.

Enchytraeus bulbosus Nielsen \& Christensen, 1963: widespread, not in strongly acidic soils, $r$ strategist, OF and soil dweller.

Enchytraeus christenseni Dózsa-Farkas, 1992: widespread but not common, wet habitats, not in strongly acidic soils, $r$-strategist, $\mathrm{OF}$ and soil dweller.

Enchytraeus lacteus Nielsen \& Christensen, 1961: widespread, not in strongly acidic soils, $r$ strategist, OF and soil dweller.

Enchytronia parva Nielsen \& Christensen, 1959: common and widespread in neutral to moderately acidic soils, probably a species complex, soil dweller, stress tolerant species adapted to acidity stress.

Fridericia bulboides Nielsen \& Christensen, 1959: widespread and common, slightly acid to slightly alkaline conditions, never in strongly acid soils, $K$-strategist, soil dweller

Fridericia christeri Rota \& Healy, 1999: Northern half of Europe, very common in Germany.

Fridericia galba (Hoffmeister, 1843): widespread and very common in Central Europe, slightly acid to slightly alkaline conditions, never in strongly acid soils, $K$-strategist, soil dweller.

Fridericia isseli Rota, 1994: widespread and common.

Fridericia maculata Issel, 1905: widespread, probably a species complex, slightly acid to slightly alkaline conditions, never in strongly acid soils, $K$-strategist, soil dweller.

Fridericia nix Rota, 1995: Italy, Germany.

Fridericia paroniana Issel, 1904: widespread and common, slightly acid to slightly alkaline conditions, never in strongly acid soils, $K$-strategist, soil dweller.
Fridericia tuberosa Rota, 1995: moist soil, widespread.

Fridericia ulrikae Rota \& Healy, 1999: Northern and Central Europe.

Fridericia viridula Issel, 1904: found in Ireland, The Netherlands, and Italy.

Fridericia glandifera Friend, 1911: few records in England, Denmark, Germany and France.

Marionina argentea (Michaelsen, 1889): very common and widespread, wet sites also aquatic, slightly salt-tolerant, slightly acid to slightly alkaline conditions, never in strongly acid soils, $K$-strategist, soil dweller.

Marionina communis Nielsen \& Christensen, 1959: widespread, fresh soils but not wet, slightly acid to slightly alkaline conditions, never in strongly acid soils, $K$-strategist, OF dweller.

A total of 5633 and 3390 individuals were identified in Spring 2016 and in Autumn 2016, respectively. The number of individuals and the percentage of enchytraeid species are presented in Table 2. In Spring, the three most abundant species were E. buchholzi $(23,6 \%), F$. galba $(14,4$ $\%$ ), and $F$. isseli (13,2 \%). In autumn, the three most abundant species were En. parva $(12,7 \%)$, F. christeri (12,2 \%), and E. buchholzi (11,8\%).

\section{DISCUSSION}

This study, in which twenty four species were found, represents the first record of enchytraeid's community in France. Schmelz \& Collado (2010) reported only four to five species identified in France: Guaranidrilus europaeus Healy, 1979; Enchytraeus varithecatus Bouguenec \& Giani, 1987; Enchytraeus doerjesi Westheide \& Graefe, 1992; Fridericia glandifera Friend, 1911 and Fridericia stephensoni Moszyński, 1933 (need to be confirmed). A bit more than 200 species are listed in the key for terrestrial enchytraeids of Europe (Schmelz \& Collado 2010). Among them, 126 have been sampled in Germany (Römbke et al. 2013), and 50 of them can be classified as common for Central Europe (Didden et al. 1997). 
Table 2. Enchytraeid density (ind. $\mathrm{m}^{-2}$ ) per species and per season (Spring and Autumn 2016). Nomenclature follows Schmelz \& Collado (2010).

\begin{tabular}{|c|c|c|c|c|c|}
\hline \multirow[b]{2}{*}{ Genus } & \multirow[b]{2}{*}{ Species } & \multicolumn{2}{|c|}{ Spring 2016} & \multicolumn{2}{|c|}{ Autumn 2016} \\
\hline & & No. of individuals & $\%$ abundance & No. of individuals & $\%$ abundance \\
\hline Achaeta & bohemica & 0 & 0.00 & 20 & 0.59 \\
\hline Achaeta & iberica & 311 & 5.52 & 186 & 5.49 \\
\hline Achaeta & pannonica & 12 & 0.21 & 34 & 1.00 \\
\hline Achaeta & unibulba & 13 & 0.23 & 28 & 0.83 \\
\hline Buchholzia & appendiculata & 238 & 4.23 & 120 & 3.54 \\
\hline Buchholzia & fallax & 27 & 0.48 & 9 & 0.27 \\
\hline Enchytraeus & buchholzi & 1330 & 23.61 & 399 & 11.77 \\
\hline Enchytraeus & bulbosus & 97 & 1.72 & 29 & 0.86 \\
\hline Enchytraeus & christenseni & 32 & 0.57 & 0 & 0.00 \\
\hline Enchytraeus & lacteus & 2 & 0.04 & 0 & 0.00 \\
\hline Enchytronia & parva & 441 & 7.83 & 432 & 12.74 \\
\hline Fridericia & bulboides & 0 & 0.00 & 31 & 0.91 \\
\hline Fridericia & christeri & 426 & 7.56 & 412 & 12.15 \\
\hline Fridericia & galba & 813 & 14.43 & 397 & 11.71 \\
\hline Fridericia & glandifera & 0 & 0.00 & 2 & 0.06 \\
\hline Fridericia & isseli & 745 & 13.23 & 386 & 11.39 \\
\hline Fridericia & maculata & 10 & 0.18 & 55 & 1.62 \\
\hline Fridericia & $n i x$ & 17 & 0.30 & 30 & 0.88 \\
\hline Fridericia & paroniana & 319 & 5.66 & 320 & 9.44 \\
\hline Fridericia & tuberosa & 254 & 4.51 & 270 & 7.96 \\
\hline Fridericia & ulrikae & 152 & 2.70 & 102 & 3.01 \\
\hline Fridericia & viridula & 62 & 1.1 & 23 & 0.68 \\
\hline Marionina & argentea & 244 & 4.33 & 37 & 1.09 \\
\hline \multirow[t]{3}{*}{ Marionina } & communis & 3 & 0.05 & 4 & 0.12 \\
\hline & NI & 85 & 1.51 & 64 & 1.89 \\
\hline & Total & 5633 & $100 \%$ & 3390 & $100 \%$ \\
\hline
\end{tabular}

When looking at the published literature on enchytraeid communities in grasslands, meadows and pastures, only forty publications could be found. Among them, some were performed under tropical climates, in Brazil (e.g. Schmelz et al. 2008). Schlaghamerský \& Kobetičová (2005) studied Enchytraeidae, Tubificidae, Aeolosomatidae in a field experiment in the Czech Republic during meadow restoration on arable land and in a well-preserved meadow nearby. They found 22 species of Enchytraeidae in the meadow and considered it as a relatively high diversity. The same authors also studied two sites in the White Carpathians (Czechia) at four dates during one year (Schlaghamerský \& Kobetičová 2006). Each sites consisted of one meadow and one cattle pasture. They found respectively 16 and 17 enchytraeid species in the two meadows. The high percentages of Fridericia spp. in all plots were considered to correspond with their rather low soil acidity. In the present study, despite the neutral $\mathrm{pH}$, we also found many Fridericia individuals and eleven out of twenty four species belonged to this genus. To our knowledge, the highest 
diversity reported in a meadow was 23 species (Schlaghamerský et al. 2007) in White Carpathians (Czechia), with twelve Fridericia species. The diversity found in our study was close to these results and thirteen species were in common. Some species such as F. galba, E. buchholzi or M. argentea appeared to be relatively well represented in the different meadows of the published studies. Contrarily, some others, such as $F$. christeri are more rarely found.

Regarding enchytraeid species distribution in European countries and soil characteristics $(\mathrm{pH}$, soil water and $\mathrm{C}_{\text {org }}$ contents), the species found in our study are in accordance with the observations of Schmelz \& Collado (2010) and Graefe \& Schmelz (1999). We found horizontal heterogeneity in the meadow concerning the occurrence of the different species of enchytraeids. This was probably due to the variations in soil properties in the plot (e.g. soil moisture, temperature, vegetation). For example, numerous $M$. argentea were found in few soil cores and absent in others. This could be mainly explained by wetter soil conditions in one part of the plot. By contrast, species such as $F$. galba, $F$. isseli, F. christeri, E. buchholzi or En. parva were observed in most of soil samples. Few species were mainly found in the soil layer at 5-10 cm depth such as Achaeta spp. or F. nix. Those observations confirm Graefe \& Schmelz study (1999) as they indicated that $A$. bohemica and $A$. pannonica are known to be soil dwellers. However, no information was found about $F$. nix habitat requirements.

We found a total of five $r$-strategists (Enchytraeus spp. and $B$. appendiculata) including one fragmenting species (B. appendiculata) among the sampled species. We also observed numerous specimens of Buchholzia sp. with two chaetae, which is unusual except for very young specimens just hatched from cocoons and not "born" by fragmentation (Schmelz pers. observ.). DNA test will confirm if a new species of Buchholzia has been found.

Acknowledgements - This study was funded by ANSES (French Agency for Food, Environmental and Occupational Health \& Safety), which provided a post-doctoral grant to Joël Amossé. We greatly thank Franck Brulle (ANSES),
Arnaud Conrad (ANSES), Jean-Pierre Pétraud and Jodie Thénard (INRA) for their useful advices on the experimental design. We also thank the staff of the INRA UMR ECOSYS of Versailles who took part in the soil core sampling and extraction for enchytraeid community, soil temperature and soil moisture measurements (F. Poiroux, V. Etiévant, J.-P. Pétraud, G. Delarue, C. Laurent and A. Vincent). Research and travel grant for Gergely Boros was financed by Campus France (Balaton project).

\section{REFERENCES}

AmossÉ, J., DózSA-FARKAS, K., BoRos, G., ROCHAT, G., SANDOZ, G., FourNiER, B., Mitchell, E.A.D. \& LE BAYON, R.C. (2016): Patterns of earthworm, enchytraeid, and nematode diversity and community structure in urban soils of different ages. European Journal of Soil Biology, 73: 46-58. doi: $10.1016 /$ j.ejsobi.2016.01.004

Clements, R.O., Bentley, B.R. \& Nuttall, R.M. (1987): The invertebrate population and response to pesticide treatment of two permanent and two temporary pastures. Annals of Applied Biology, 111(2): 399-407.

doi: $10.1111 / \mathrm{j} .1744-7348.1987 . t b 01467 . \mathrm{x}$

Davidson, D.A., Bruneau, P.M.C., Grieve, I.C. \& WILSON, C.A. (2004): Micromorphological assessment of the effect of liming on faunal excrement in an upland grassland soil. Applied Soil Ecology, 26(3): 169-177. doi: 10.1016/j.apsoil.2004.01.006

DidDEN, W.A.M. (1993): Ecology of terrestrial Enchytraeidae. Pedobiologia, 37: 2-29.

DidDen, W.A.M., Fruend, H.L. \& Graefe, U. (1997): Enchytraeids. In. BENCKISER, G. (Ed.) Fauna in soil ecosystems. Recycling processes, nutrient fluxes and agricultural production. Dekker, M., Inc. New York, p. 135-172.

FORSTER, B., RÖMBKE, J. \& KNACKER, T. (1992): Comparison of the effects of pesticides on soil microflora and mesofauna in two different ecosystems. In. ANDERSON, J.P.E., ARNOLD, D.J., LeWIS, F. \& Torstensson, L. (Eds.) Proceedings of the international symposium on environmental aspects of pesticide microbiology. Sigtuna, Sweden, p. 234-239.

FrancinI, G., Litri, M., ManNisto, M., STARK, S., KytovitTA, M.M. (2014): Response to reindeer grazing removal depends on soil characteristics in low Arctic meadows. Applied Soil Ecology, 76: 1425. doi: 10.1016/j.apsoil.2013.12.003 
GRAEFE, U. \& SchMELZ, R.M. (1999): Indicator values, strategy types and life forms of terrestrial Enchytraeidae and other microannelids. In. SCHMELZ, R.M. \& SÜHLO, K. (Eds.) Newsletter on Enchytraeidae 6, Prodeecings of the $3^{\text {th }}$ International Symposium on Enchytraeidae. Universitätsverlag Rasch, Osnabrück, p. 59-67.

Kobeticova, K. \& SCHLAGHAMERSKÝ, J. (2003): On the efficiency of three schemes of enchytraeid wet funnel extraction. In. DIDDEN, W A. M. \& VAN VLIET, P. (Eds.) Newsletter on Enchytraeidae 8. Proceedings of the $5^{\text {th }}$ International Symposium on Enchytraeidae, Wageningen University, Wageningen, p. 25-31.

MARTIN, N.A. (1975): Effect of four insecticides on the pasture ecosystem: IV. Enchytraeidae and Diptera larvae heat-extracted in water-filled funnels. New Zealand Journal of Agricultural Research, 18: 313-315. doi: $\underline{10.1080 / 00288233.1975 .10423650}$

O'CONNOR, F.B. (1959): Extraction of enchytraeid worms from a coniferous forest soil. Nature, 175: 815-816. doi: $\underline{10.1038 / 175815 b 0}$

Pelosi, C. \& RömbKe, J. (2016) Are Enchytraeidae (Oligochaeta, Annelida) good indicators of agricultural management practices? Soil Biology and Biochemistry, 100: 255-263. doi: $\underline{10.1016 / j . s o i l b i o .2016 .06 .030}$

RÖMBKE, J. JÄNSCH, S., HÖFER, H., HORAK, F., ROßNickoll, M., Russell, D., Burkhardt, U. \& TOSCHKI, A. (2013): State of knowledge of enchytraeid communities in German soils as a basis for biological soil quality assessment. Soil Organisms, 85: 123-146.

SCHLAGHAMERSKÝ, J. \& KobetičOVÁ, K. (2005): A small annelid community (Enchytraeidae, Tubificidae, Aeolosomatidae) during meadow restoration on arable land and in a nearby well-preserved meadow. Proceedings of the Estonian Academy of Sciences, Biology, Ecology, 54(4): 323-330.

SCHLAGHAMERSKÝ, J. \& KOBETIČOVÁ, K. (2006): The impact of cattle pasturage on small annelids (Annelida: Enchytraeidae, Tubificidae, Aeolosomatidae) in grasslands of the White Carpathians (Czech Republic). European Journal of Soil Biology, 42: 305-309. doi: 10.1016/j.ejsobi.2006.07.037

SchlaghamerskÝ, J., Sidova, A. \& PižL, V. (2007): From mowing to grazing: Does the change in grassland management affect soil annelid assemblages? European Journal of Soil Biology, 43: 72-78. doi: 10.1016/j.ejsobi.2007.08.054

SChMElz, R.M. \& COLlado, R. (2010): A guide to European terrestrial and freshwater species of Enchytraeidae (Oligochaeta). Soil Organisms, 82(1): $1-176$.

Schmelz, R.M., Collado, R. \& RöMBKe, J. (2008): Mata Atlântica enchytraeids (Parana, Brazil): The genus Achaeta (Oligochaeta, Enchytraeidae). Zootaxa, 1809: 1-35. doi: 10.5281/zenodo.182758

SokoŁowsKa, L. \& SeniczaK, S. (2005): The effect of cattle liquid manure fertilization on alternating grassland and some groups of soil mesofauna. Folia Biologica-Krakow, 53: 133-137. doi: $\underline{10.3409 / 173491605775789407}$

UNITED STATES DEPARTMENT OF AGRICULTURE (USDA) (1975): Soil taxonomy: a basic system of soil classification for making and interpreting soil surveys. Soil Conservation Service, Agriculture Handbook No. 436. Washington DC, 754 pp.

VAN Vliet, P.C.J. \& DE GOEDE, R.G.M. (2006): Effects of slurry application methods on soil faunal communities in permanent grassland. European Journal of Soil Biology, 42: 348-353. doi: $10.1016 /$ j.ejsobi.2006.09.004 